\title{
SIMULATE PLANT GROWTH RESPONSE TO BIOCHAR ON UPLAND RICE-COWPEA INTERCROP IN A FERRIC LUVISOLS SOIL IN GHANA
}

\author{
Frimpong-Manso $\mathrm{J}^{1^{*}}$ and Ganiyu $\mathrm{SA}^{2}$ \\ ${ }^{1}$ CSIR-Soil Research Institute, Kwadaso-Kumasi, Ghana \\ ${ }^{2}$ Department of Agricultural Engineering, University for Development Studies, Ghana
}

\begin{abstract}
A field experiment was conducted on a ferric luvisols in the Guinea Savannah zone, to compare the growth and yield of rice-cowpea intercrop in which three different biochar sources (groundnut shells, poultry manure, and corn cobs) was enhanced with inorganic fertilizer to boost their cowpea $\mathrm{N}$ and $\mathrm{P}$ content and were integrated into the soil at a rate of $5 \mathrm{t} \mathrm{ha}^{-1}$ with a depth of $20 \mathrm{~cm}$. It was carried out in 2018-2019 cropping season. A randomized complete block with 4 replications was used. The Agricultural Production Systems Simulator (APSIM) was tested against this dataset. The effect of biochar treatments greatly increases growth of rice. The model performed better in simulating the experimental $\mathrm{P}$ response of the upland rice at high $\mathrm{N}$ levels. The yield of rice was predicted $\left(r^{2}=0.74\right.$ and 0.85$)$ in 2018 and 2019 respectively. Biochar amendments to input parameters for the $\mathrm{P}$ model, particularly in relation to $\mathrm{P}$ amount and uptake for subterranean soil layers were enhanced and fit between experimental and predicted results. The findings showed that cowpea intercrop could be combined with three different sources of biochar to improve soil fertility and crop productivity in areas where $\mathrm{N}$ and $\mathrm{P}$ are restricted. APSIM performed well in predicting the growth of cowpea well-supplied with $\mathrm{P}$, and the residual biochar and $\mathrm{N}$ benefits to a succeeding upland rice crop, including the response to additional inputs of $\mathrm{N}$ fertilizer.
\end{abstract}

Keywords: Agricultural Production Systems simulator (APSIM), soil layer, biochar source, amendment, rice-cowpea intercrop system, $\mathrm{C} / \mathrm{N}$ ratio

\section{Introduction}

In most tropical agricultural soils, severe soil fertility depletion and decreased agricultural output due to nutrient imbalances and a decrease in soil organic matter (SOM) are key restrictions (Lal, 2015, 2020). Biochar improves crop biomass and yield through improving chemical, physical, and biological soil qualities (Glaser et al., 2002; Kookana et al., 2011). The use of biochar also augments soil properties, decreasing potential acidity and increasing available $\mathrm{P}$ and $\mathrm{K}$. The application of biochar (charcoal or biomass-derived black carbon (C) to soil is further proposed as a novel approach to establish a significant, long-term, sink for atmospheric carbon dioxide in terrestrial ecosystems. Biochar has a number of advantages over other additions in terms of soil ecosystem functions, including the ability to improve soil fertility and nutrient retention more effectively than uncharred organic matter (Lehmann et al., 2006).

Biochar can comprise substantial amounts of carbon and $\mathrm{P}$ as well as N. For this reason, $\mathrm{P}$ is occasionally added because of greater limitation to crop growth compared to $\mathrm{N}$ in low-input farming 
systems. The nitrogen concentration of small-scale farms has been discovered to be low (Laird et al., 2009; Simpson et al., 2011; Ayaga et al., 2006), questions rise as to whether a farmer would get a higher produce from application of biochar to a cowpea crop in its place of a rice, and to what degree is the residual $\mathrm{N}$ benefit of the cowpea to the following upland rice crop improved by the cowpea responding to the applied biochar. Organic materials like biochar and biochar compost are used to lower production costs also improving soil health and increasing productivity per unit area on a longterm basis (Agegnehu et al., 2017). Research/studies by Musah et al., (2013) in Guinea Savannah zone in Ghana has addressed these two queries. That is the case of low and high pyrolysis quality of biochar uses in upland rice-cowpea intercrops grown on ferric luvisols soil.

A distinct nature of this studies is that cowpea and inorganic fertilizer treatments were added to aid and to measure the upland rice-cowpea intercrop responses to the $\mathrm{N}$ and $\mathrm{P}$ content of the biochar. Several of the input parameters for simulation, particularly for soil and biochar characteristics, were identified while monitoring the experiments, which were very broad. The data set was used to evaluate the efficacy of APSIM and its new modules, Soil P and Biochar, in simulating the complex connections between climate, soil, and plant growth and yield in rice crops.

A complication, however, is that currently APSIM rice-cowpea intercrop module is only able to respond to low soil P conditions to simulate P stress on plant growth (Dimes and Revanuru, 2004). However, it was felt that the simulated total biomass response of APSIM rice-cowpea intercrop could be used as a substitute for the experimental rice responses. Within APSIM, the rice and maize models are based on a common crop template and share the same procedures to act with the soil water and nutrient ( $\mathrm{N}$ and $\mathrm{P}$ ) modules to make available for growth demand. This study validates on the performance of APSIM to simulate parts of the experimental rice-cowpea intercrop responses to $\mathrm{N}$ and $\mathrm{P}$ inputs, and the biochar benefits to a succeeding rice crop.

\section{Materials and Methods}

\section{Study site}

Experiments were conducted at the Farming for the Future, University for Development Studies (UDS), Nyankpala in the Northern Region of Ghana (latitude 09.246070N and longitude 000.589920W; altitude $252 \mathrm{~m}$ ). The area has a unimodal rainfall pattern (April - October) with an annual rainfall of 800-1100 mm (Ekekpi and Kombiok 2008). The dry season starts from November to March with day and night temperatures of $33^{\circ} \mathrm{C}-39^{\circ} \mathrm{C}$ and $20^{\circ} \mathrm{C}-26^{\circ} \mathrm{C}$ respectively (Kombiok et al., 2005; Konlan, 2010). The soil profile has been classified as Nyankpala series (Ferric luvisols and Plinthic acrisols) (FAO-UNESCO, 1988; Imoro et al., 2012).

\section{Biochar preparation}

Three different sources feedstocks were produced from slow and high pyrolysis of groundnut shells, corn cobs and poultry manure at $400^{\circ} \mathrm{C}-700^{\circ} \mathrm{C}$ with a dwelling time of 24 hours under oxygenlimited conditions in a reactor, followed by water and air cooling of charred feedstock to room temperature before grinding. Chemical characteristics of the biochar applied are shown in Table 1. Organic carbon was determined by the wet combustion method according to Nelson and Sommers (1996). Total nitrogen was determined by the kjeldahl method Bremner (1965). Available potassium 
extracted using the Bray's no. 1 solution was determined directly using the Gallenkamp flame analyzer. Available phosphorus was determined according Bray and Kutz (1945).

Table 1: Basic biochar properties used for simulations

\begin{tabular}{lllllllll}
\hline Feedstock & Pyrolysis & $\begin{array}{l}\mathrm{pH} \\
1: 5\end{array}$ & $\begin{array}{l}\text { C.E.C } \\
\text { me } 100 \mathrm{~g}^{-1}\end{array}$ & $\begin{array}{l}\mathrm{N} \\
\%\end{array}$ & $\begin{array}{l}\mathrm{P} \\
\%\end{array}$ & $\begin{array}{l}\mathrm{K} \\
\%\end{array}$ & $\begin{array}{l}\text { C:N } \\
\text { ratio } \\
(-)\end{array}$ & $\begin{array}{l}\text { Fraction C } \\
(0-1)\end{array}$ \\
\hline Biochar Corn cobs & High & 6.67 & 118.26 & 0.95 & 0.21 & 0.45 & 11.0 & 0.129 \\
Biochar Poultry manure & Low & 9.29 & 125.63 & 2.19 & 0.5 & 0.47 & 10.5 & 0.324 \\
Biochar Groundnut shells & Low & 11.13 & 85.52 & 1.34 & 0.13 & 0.74 & 12.3 & 0.243 \\
\hline
\end{tabular}

\section{Experimental design and treatments}

The experiment was arranged in randomized complete blocks design (RCBD) with 4 replications. Plot sizes of $1026 \mathrm{~m}^{2}$ and were demarcated into $3 \times 4 \mathrm{~m}$ for all treatments. Treatments were applied on June 2017 to experimental plots on a dry weight basis at $5 \mathrm{t} \mathrm{ha}^{-1}$. The test crops were NERICA 14 rice (Oryza sativa L.) and Padituya cowpea (Vigna unguiculata L.). Treatments comprise of absolute control, sole cowpea, 90N60P60K, biochar poultry manure+45N:30P:30K+cowpea, biochar groundnut shells $+45 \mathrm{~N}: 30 \mathrm{P}: 30 \mathrm{~K}+$ cowpea, biochar corn cobs+45N:30P:30K+cowpea, biochar poultry manure $+45 \mathrm{~N}: 30 \mathrm{P}: 30 \mathrm{~K}$, biochar groundnut shells $+45 \mathrm{~N}: 30 \mathrm{P}: 30 \mathrm{~K}$ and biochar corn cobs+45N:30P:30K. Then top-dress with nitrogen levels in the form of urea $30 \mathrm{~kg} \mathrm{ha}^{-1} \mathrm{~N}$ eight (8) weeks after transplanting. Rice-cowpea intercrop plots were treated with Roundup (Glyphosate) of $300 \mathrm{ml}$ per knapsack as pre-emergence and Gramoxone (paraquat) of $200 \mathrm{mls}$ per knapsack postemergence herbicides and hand weeded thrice during the season. Nursery seed bed was prepared to a finer tilth to allow uniform crop establishment. One fifty (150) seeds per square meter were drilled at a row spacing of $20 \mathrm{~cm}$ and sow seed 2-4 cm deep. Biochar that preceded the experiments were incorporated in early May 2017 for nursery. The applied biochar was incorporated into the $20 \mathrm{~cm}$ surface soil layer. Short duration (85 days) upland rice (Nerica 14) was transplanted by hand and cowpea (padituya), was sown on next day. Rice seedlings were transplanted at a spacing of $20 \mathrm{~cm}$ by $20 \mathrm{~cm}$ at the rate of $75 \mathrm{~kg} \mathrm{ha}^{-1}$ in sole crop, Cowpea seeds were planted at the rate of $25 \mathrm{~kg} \mathrm{ha}^{-1}$ at the spacing of $60 \mathrm{~cm}$ by $20 \mathrm{~cm}$ in pure stand. The space between any rice row and any of the cowpea rows was $60 \mathrm{~cm}$ apart. EmaStar $112 \mathrm{EC}$ (Emamectin benzoate $48 \mathrm{~g}^{-1}+$ Acetamipride $64 \mathrm{~g}^{-1}$ ) $10 \mathrm{mls}$ per knapsack was used to treat aphids and spittle bug on the rice-cowpea intercrop plots. The cowpea was harvested at three months, while rice was harvested at four months after planting.

\section{Simulations}

Soil parameters and initial conditions used to simulate experiments on the ferric luvisols soils are set out in Tables 2. Analysis of the moisture content and water potentials determinations taken throughout the rice-cowpea crops provided estimates for the crop lower limit and the drained upper limit water contents in each treatment of the soil. Concentrations of organic carbon (OC), and total $\mathrm{N}$ and the amounts of soil water were measured. Bulk density and CEC values were estimated. P sorption characteristics for surface layers were known (Puziy et al., 2002), data for the other layers were estimates. Higher values (stable soil organic matter not contributing to inorganic nitrogen quantity) have been set using \% OC in the 0-30 cm layer as a guide and based on experience in setting this parameter (Verheijen et al., 2010). Carbon in biochar have contributed to the soil-crop and have been 
reported for the guinea savanna environment (Baatuuwie et al., 2020), resulting in abruptly high biomass yields on the $\mathrm{N}$ poor soils. To increase the soil $\mathrm{N}$ quantity and include the effects of $\mathrm{N}$ additions from the biochar, altered $\mathrm{N}$ (fbiom) in the soil $0-30 \mathrm{~cm}$ was calibrated aloft until there was a bond between simulated and measured biomass yield for the absolute control treatments. Similarly, altered $\mathrm{P}$ values in Tables 2 were adjusted for the soils, to give practical prediction of observed yields in the existence of acceptable $\mathrm{N}$.

Table 2. Soil profile parameters used in this study

\begin{tabular}{|c|c|c|c|c|c|}
\hline Soil Layer & 1 & 2 & 3 & 4 & 5 \\
\hline Layer thickness $(\mathrm{cm})$ & $0-15$ & $15-30$ & $30-60$ & $60-90$ & $90-120$ \\
\hline \multicolumn{6}{|l|}{ Soil water parameters } \\
\hline $\begin{array}{l}\mathrm{BD} \\
\left(\mathrm{g} \mathrm{cm}^{-3}\right)\end{array}$ & 1.58 & 1.62 & 1.57 & 1.59 & 1.57 \\
\hline $\operatorname{SAT}\left(\mathrm{mm}^{-1}\right)$ & 0.354 & 0.358 & 0.368 & 0.342 & 0.339 \\
\hline $\operatorname{DUL}\left(\mathrm{mm}^{-1}\right)$ & 0.202 & 0.204 & 0.201 & 0.198 & 0.132 \\
\hline $\operatorname{LL} 15\left(\mathrm{~mm}^{-1}\right)$ & 0.050 & 0.106 & 0.153 & 0.128 & 0.198 \\
\hline \multicolumn{6}{|l|}{ Soil-C parameters } \\
\hline $\mathrm{OC}(\%)$ & 0.47 & 0.41 & 0.33 & 0.38 & 0.33 \\
\hline $\mathrm{pH}(\mathrm{H} 20)$ & 4.66 & 4.66 & 4.66 & 4.56 & 4.56 \\
\hline finerta & 0.36 & 0.36 & 0.70 & 0.90 & 0.90 \\
\hline fbiomb & 0.016 & 0.02 & 0.02 & 0.01 & 0.01 \\
\hline \multicolumn{6}{|l|}{ Soil P parameter } \\
\hline $\begin{array}{l}\text { Labile P } \\
\left(\mathrm{mg} \mathrm{kg}^{-1}\right)\end{array}$ & 11.6 & 5.8 & 5.0 & 2.0 & 1.0 \\
\hline $\mathrm{P}$ sorption $\left(\mathrm{mg} \mathrm{kg}^{-1}\right)$ & 60 & 80 & 150 & 180 & 200 \\
\hline
\end{tabular}

Soil parameterization of ferric Luvisols at farming for the future, UDS experimental farm to specify APSIM simulations. LL, lower limit; DUL, drained upper limit; SAT, saturated volumetric water content; BD, bulk density; OC, organic carbon; Fbiom, non-inert fraction of microbial C; and Finert, inert fraction of organic $\mathrm{C}$.

\section{Rice-cowpea Intercropping system simulation}

An upland rice transplanting and sowing of cowpea was simulated on July 2018 and 2019, with plant population set to 10 plants $\mathrm{m}^{-2}$ (the observed plant stands at harvest). Crop parameters for upland rice Nerica 14 were found to best estimated the duration of the rainy season. Fertilizer was broadcast on August 2018 and 2019 (90N: 60P:60K) and 45N:30P:60K) and Sept 2018 and 2019 (30N). To 
evaluate model predictions, simulated upland rice biomass was compared with the observed total biomass of rain season upland rice.

The APSIM modules were to simulate intercropping systems as part of a project aimed at growth response to biochar application of rice-cowpea intercrops grown under variable biochar and inorganic $\mathrm{N}$ and $\mathrm{P}$ on a Ferric luvisols soil. Rice-cowpea intercrop for the main cropping seasons were simulated for soil from each treatment using the data in (Table 3), except in this case it was assumed that there was no P constraint. Simulations began on June 11 and a short duration cowpea was planted on 22 July, with a population of 33 plants $\mathrm{m}^{-2}$. After grain harvest, removal of cowpea biomass was simulated on 4 November. Upland rice NERICA 14WAB 880-1-32-1-2-P1-HBWAB 56-50 / CG $14 / / 2 * \mathrm{WAB} 56-50$ was planted on 21 and 29 July 2018 and 2019 respectively with a population of 13.8 plants $\mathrm{m}^{-2}$ for the ferric luvisols. Two $\mathrm{N}$ fertilizer treatments for the rainy season rice were simulated; 60 and $30 \mathrm{~kg} \mathrm{~N} \mathrm{ha}^{-1}$, with fertilizer applied as per the experimental details described above for rainy season. To assess model predictions for upland rice, simulated biomass is compared to observed biomass from the 60P treatment (adequate $\mathrm{P}$ conditions). To assess simulation of upland rice response on moisture content following cowpea, simulated biomass is compared to observed biomass for moisture content receiving $30 \mathrm{~kg} \mathrm{Pt} \mathrm{ha}^{-1}$. Inadequate $\mathrm{N}$ is a constraint to crop growth is simulated. Atakora et al., 2015; Owusu-Bennoah et al., 1995 found that $\mathrm{P}$ is the second most limiting nutrient in soils in the Guinea Savanna agro-ecological zone in the region, which is consistent with findings from earlier study in the region.

Table 3: Soil fertility treatments used in the short-term experiment at Nyankpala

\begin{tabular}{|c|c|c|c|c|}
\hline Treatment & Activity & 2017 & 2018 & 2019 \\
\hline Absolute Control & None & None & None & None \\
\hline NPK Fertilizer & $\begin{array}{l}\text { Band } \\
\text { placement }\end{array}$ & None & $90,60,60 \mathrm{~kg}$ ha- 1 & $90,60,60 \mathrm{~kg}$ ha- 1 \\
\hline Biochar poultry manure & Incorporation & 5 t ha-11y-1 biochar & None & None \\
\hline Biochar groundnut shells & Incorporation & 5 t ha- $11 y-1$ biochar & None & None \\
\hline Biochar corncobs & Incorporation & 5 t ha- 1 y-1 biochar & None & None \\
\hline $\begin{array}{l}\text { Biochar poultry manure } \\
+ \text { NPK fertilizer }\end{array}$ & $\begin{array}{l}\text { Incorporation } \\
\& \text { band } \\
\text { placement }\end{array}$ & 5 t ha- $11 y-1$ biochar & $45,30,30 \mathrm{~kg}$ ha- 1 & $45,30,30 \mathrm{~kg}$ ha- 1 \\
\hline $\begin{array}{l}\text { Biochar corncobs }+ \text { NPK } \\
\text { fertilizer }\end{array}$ & $\begin{array}{l}\text { Incorporation } \\
\& \text { band } \\
\text { placement }\end{array}$ & $5 \mathrm{t}$ ha- $11 \mathrm{y}-1$ biochar & $45,30,30 \mathrm{~kg}$ ha- 1 & $45,30,30 \mathrm{~kg}$ ha- 1 \\
\hline $\begin{array}{l}\text { Biochar groundnut shells } \\
+ \text { NPK fertilizer }\end{array}$ & $\begin{array}{l}\text { Incorporation } \\
\& \text { band } \\
\text { placement }\end{array}$ & 5 t ha- $11 y-1$ biochar & $45,30,30 \mathrm{~kg}$ ha- 1 & $45,30,30 \mathrm{~kg}$ ha- 1 \\
\hline
\end{tabular}

Nitrogen (N) 45 Phosphorus (P) 30 Potassium (K) 30

Three different sources of biochar treatments were applied once throughout three years (2017-2019) cropping seasons. 


\begin{tabular}{|l|l|l|}
\hline $\begin{array}{l}\text { Determination of Organic } \\
\text { Carbon, }\end{array}$ & Determination of Total Nitrogen & $\begin{array}{l}\text { Determination of Bulk } \\
\text { Density }\end{array}$ \\
\hline $\begin{array}{l}\text { The Walkley and Black (1935) } \\
\text { procedure was used for Soil } \\
\text { organic carbon determination }\end{array}$ & $\begin{array}{l}\text { Analysis Total soil nitrogen was } \\
\text { assessed using the Kjedahl } \\
\text { method by Bremner (1965). }\end{array}$ & $\begin{array}{l}\text { Soil bulk density, } p b, \text { the dry } \\
\text { density of the soil samples } \\
\text { was determined from soil } \\
\text { core collected from the field } \\
\text { with core sampler using the } \\
\text { Klute (1986). Bulk density } \\
\text { was calculated using the } \\
\text { formula by Blake, (1986) } \\
\text { described. }\end{array}$ \\
\hline
\end{tabular}

\section{Result}

- Control - Measured — Simulated Control — Simulated Measured

\section{A. $90 N 60 P 60 K$}
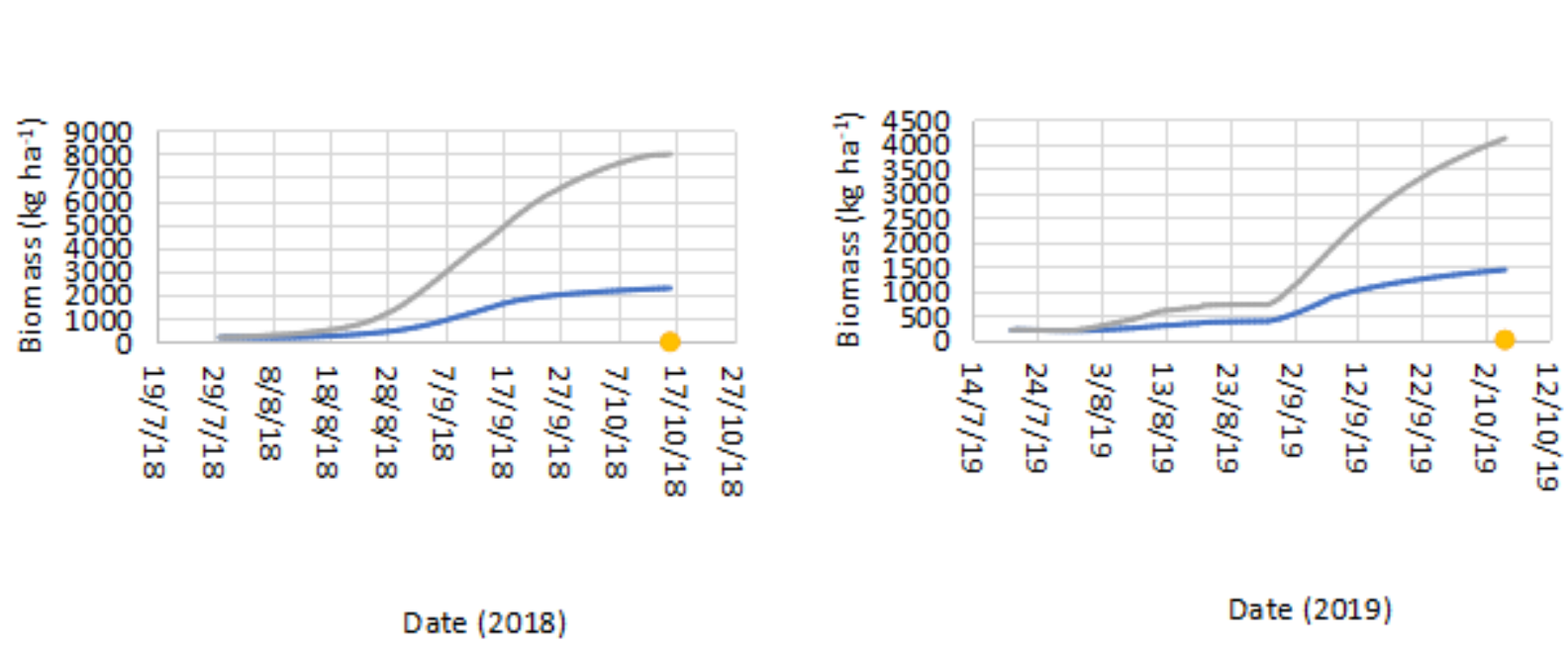

Date (2019) 
B. Char groundnut shells +45 N30P $30 K$

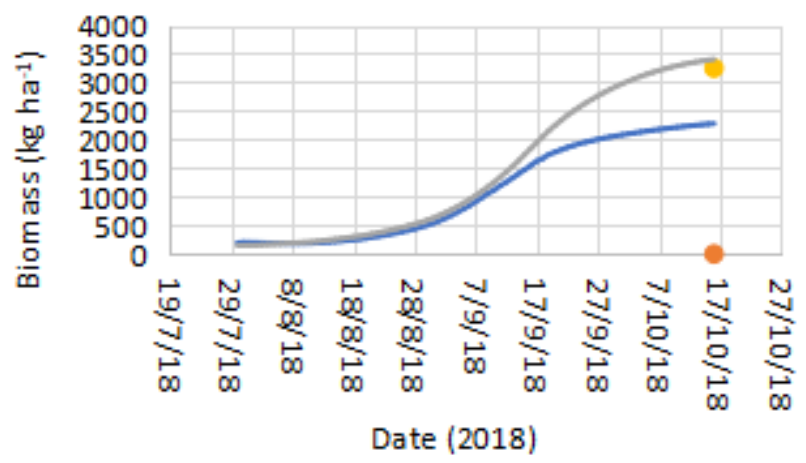

C. Char corncobs $+45 N 30 P 30 K$

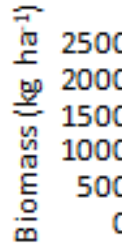

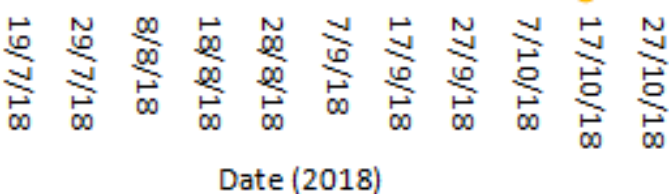

D. Char poultry $+45 \mathrm{~N} 30 \mathrm{P} 30 \mathrm{~K}$
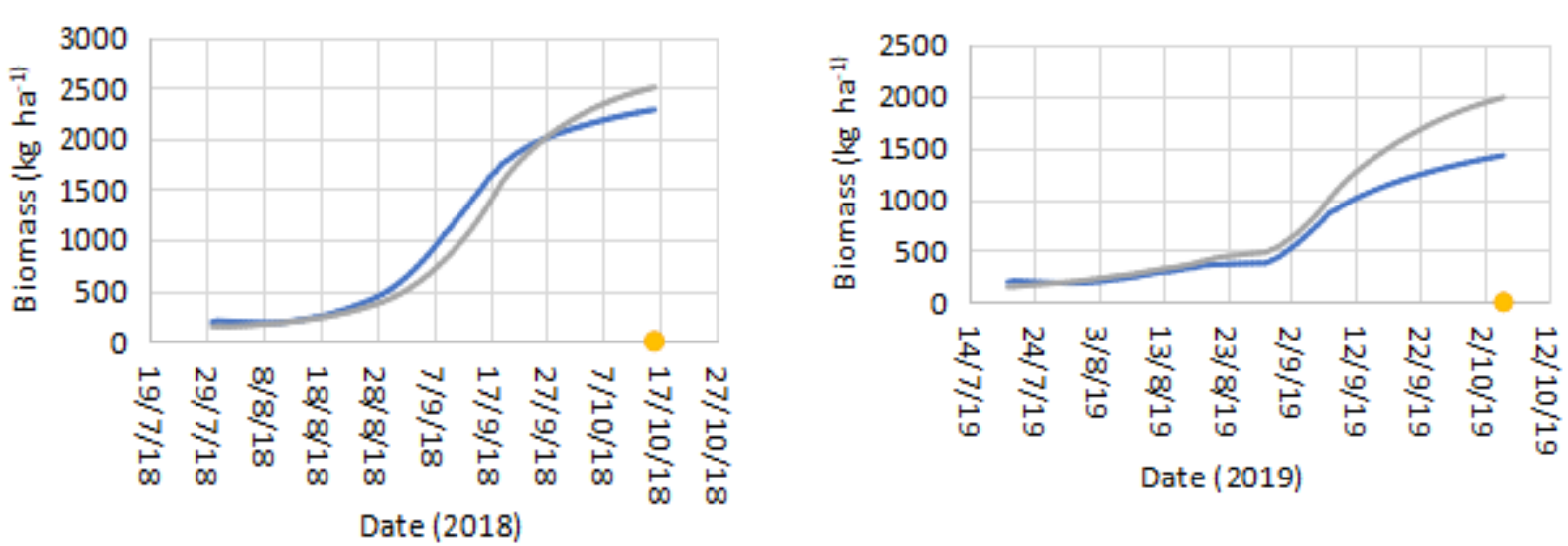
E. Char corncobs $+45 N 30 P 30 K+$ cowpea

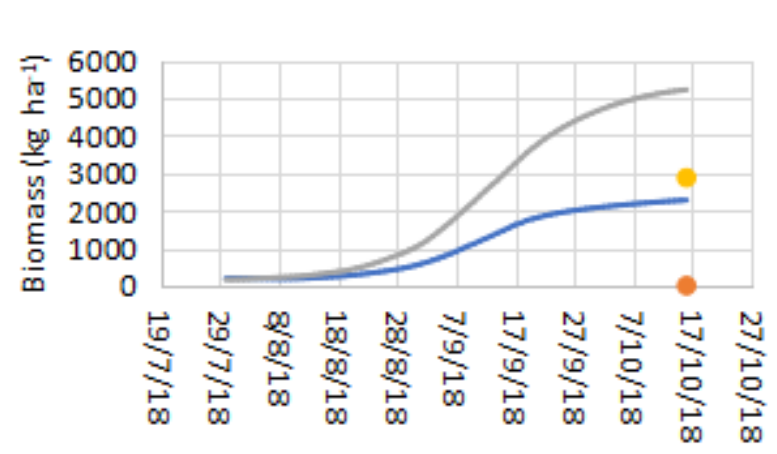

Date (2018)

\section{F. Char poultry+45N30P30K+cowpea}
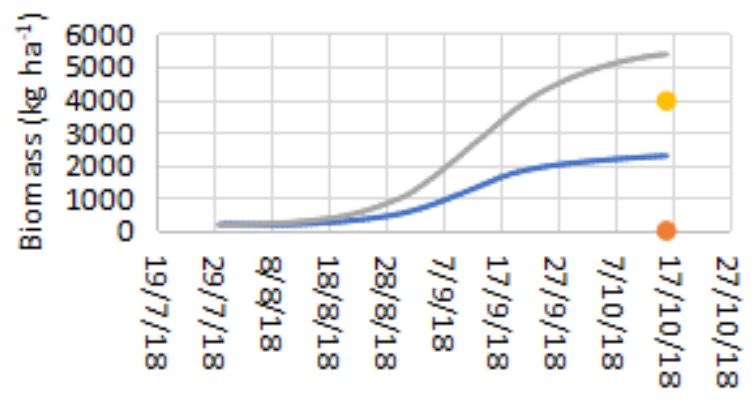

Date (2018)

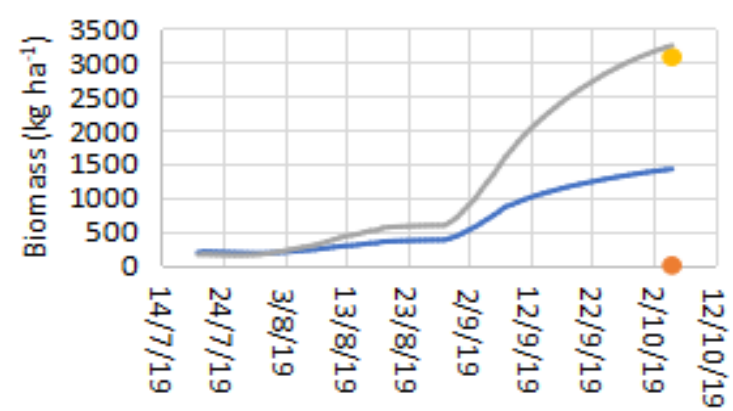

Date (2019)

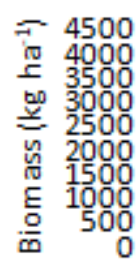

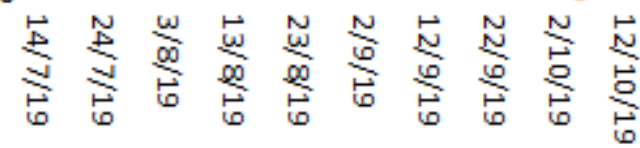

Date (2019)

G.Char groundnut shells+45N30P30K+cowpea
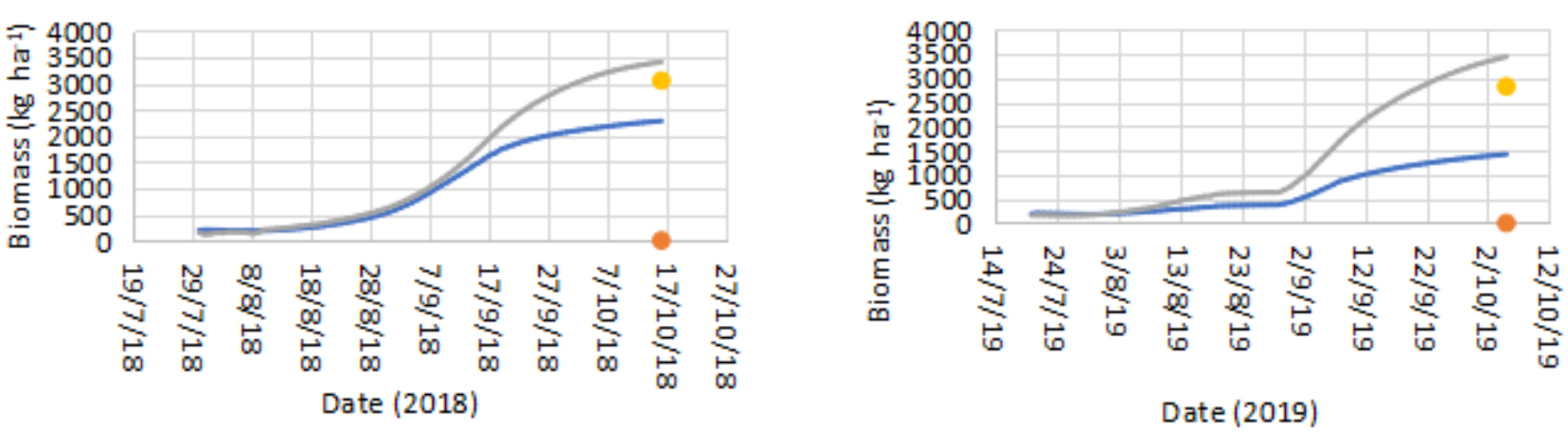

Figure 1: Simulated and observed biomass responses of upland rice crops on ferric luvisols soil 

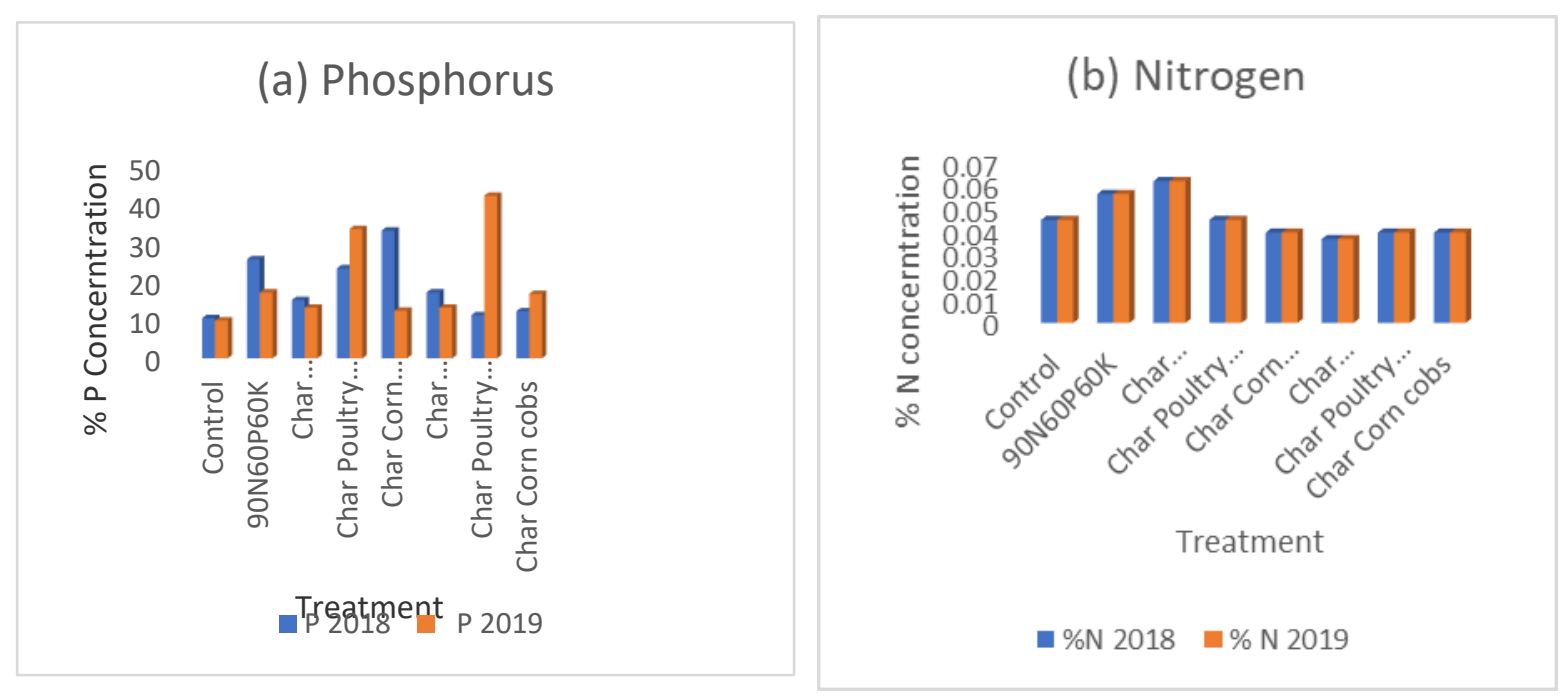

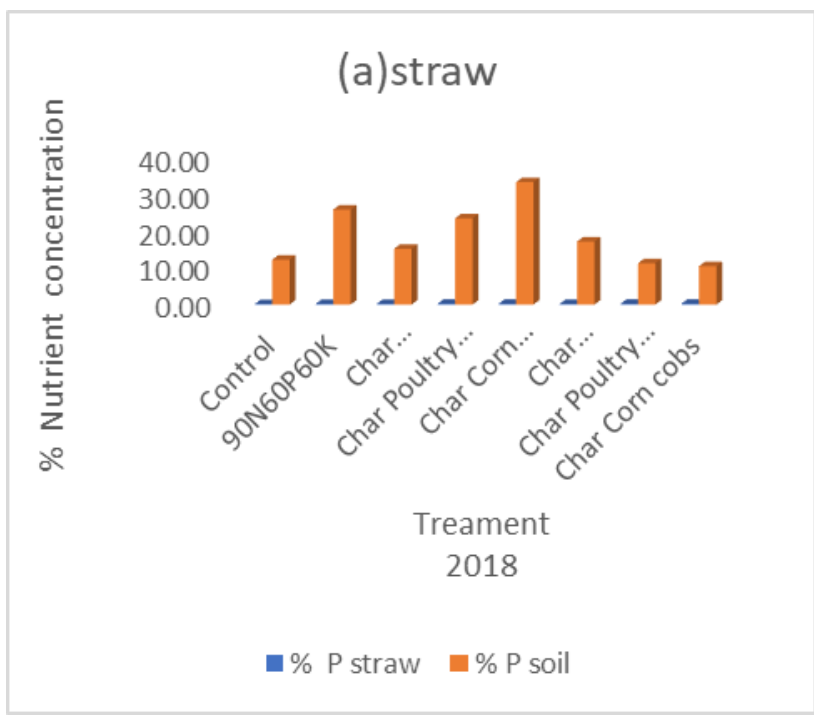

A. Developmental Stage

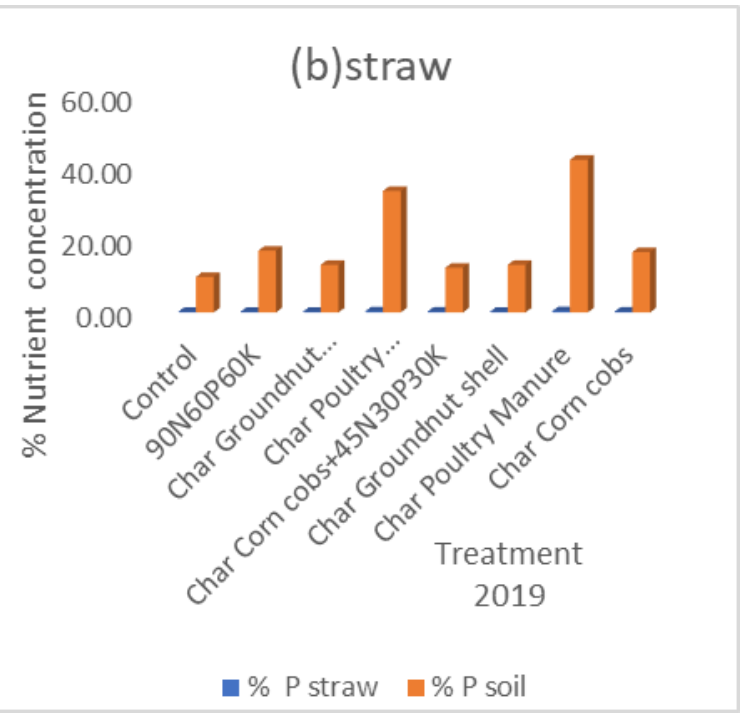

B. Developmental stage

Figure 2. Comparison of measured $P$ and $N$ concentration in rice plant under the biochar poultry manure, biochar corncobs and biochar groundnut shells treatments concentrations of straw and soil defined in APSIM (Developmental stages are: 1 - sowing, 2 - germination, 3 -emergence, 4 - end of juvenile stage, 5 -floral initiation, 6-flowering, 7 - start grain filling, 8 - end of grain filling, 9 - maturity)
- Control
Measured
— Simulated Control
Simulated Measured

\section{A. $90 N 60 P 60 K$}
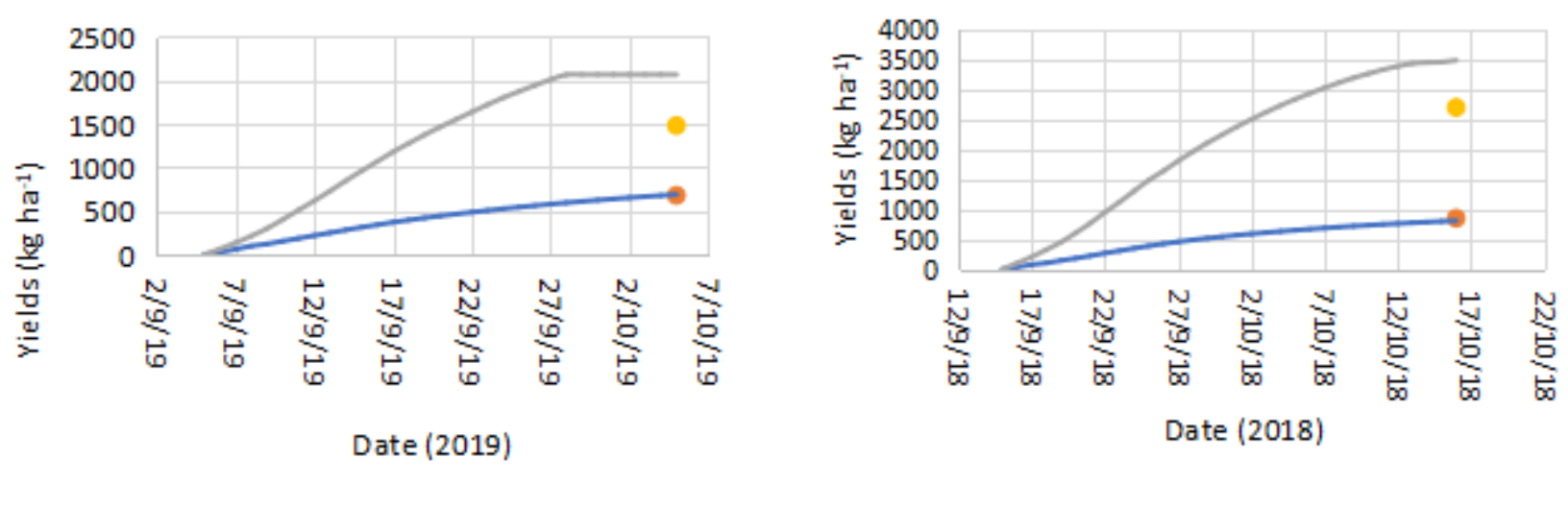
B. Char groundnut shells $+45 N 30 P 30 K$

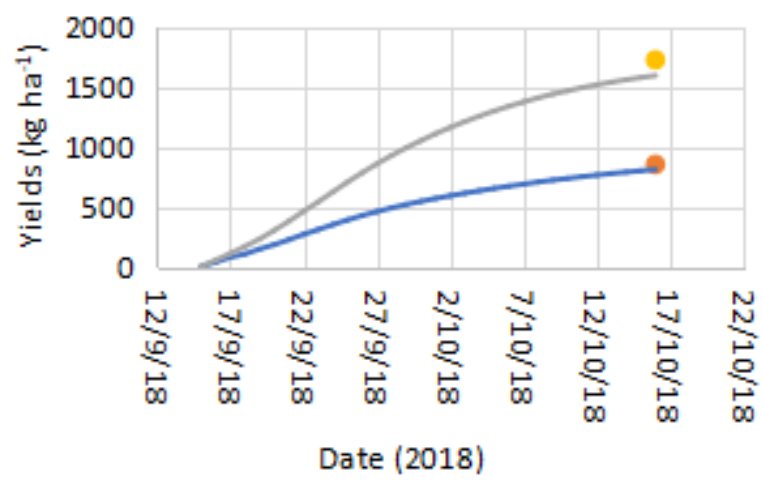

C. Char corn cobs $+45 N 30 P 30 K$

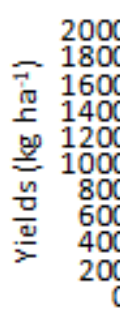

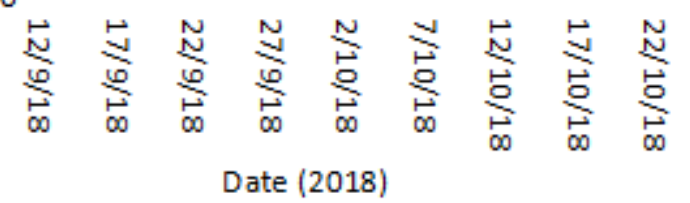
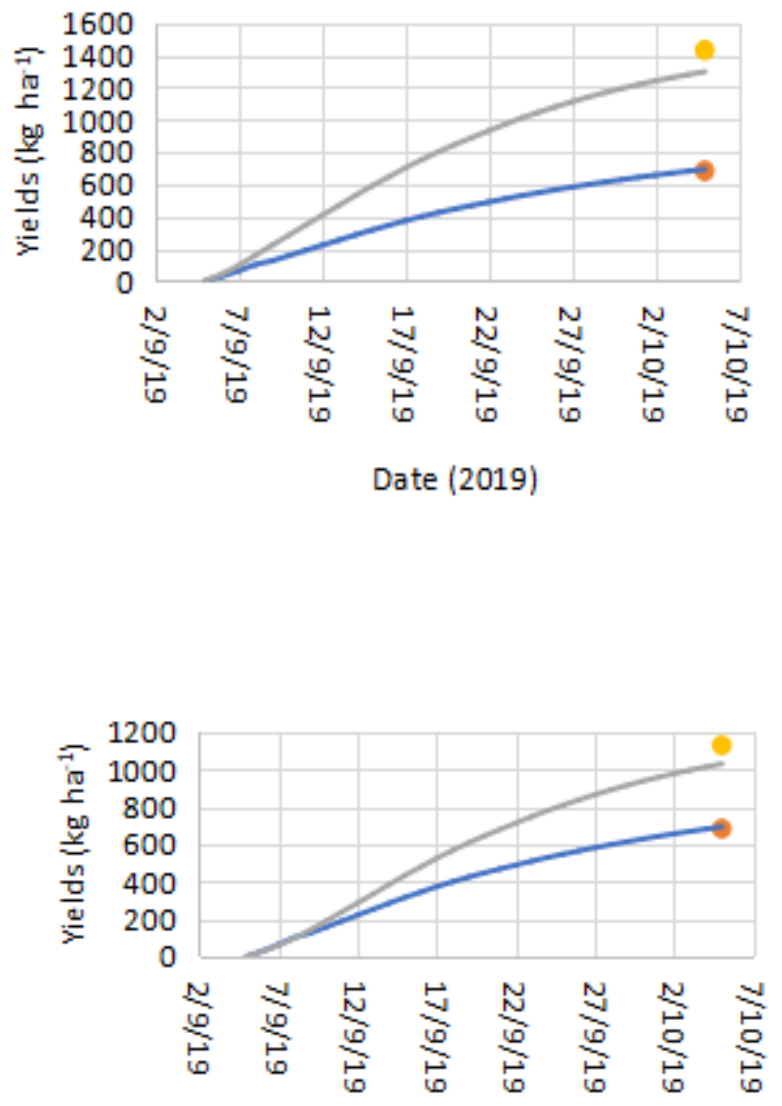

Date (2019) 
D Char poultry $+45 \mathrm{~N} 30 \mathrm{P} 30 \mathrm{~K}$

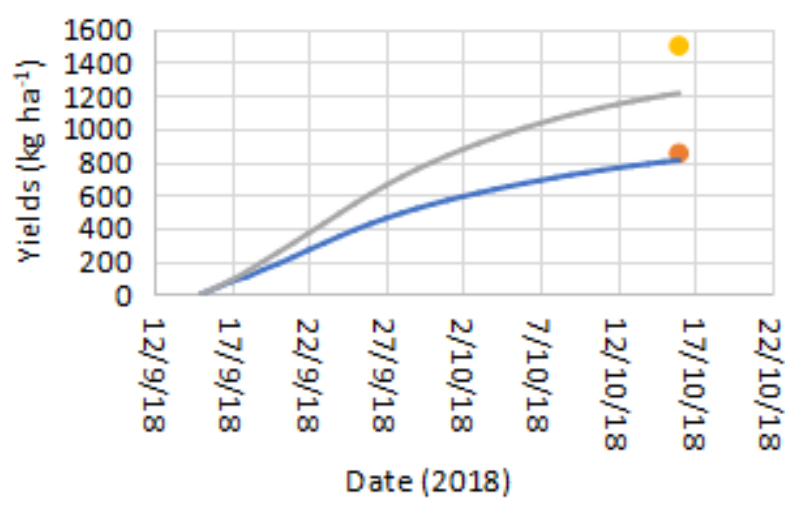

$D$

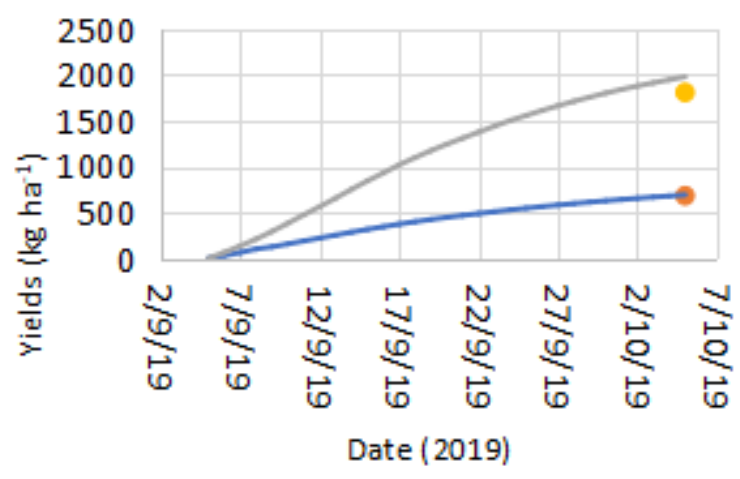

E. Char groundnut shells $+45 N 30 P 30 K+$ cowpea

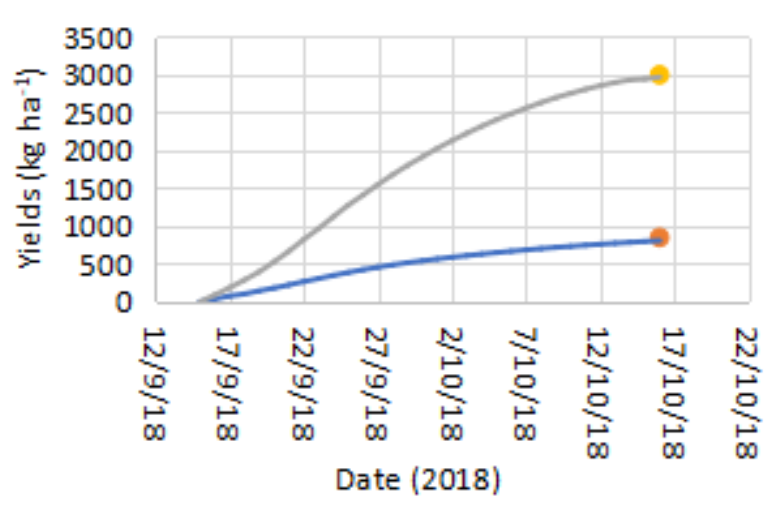

F. Char poultry+45N30P30K+cowpea
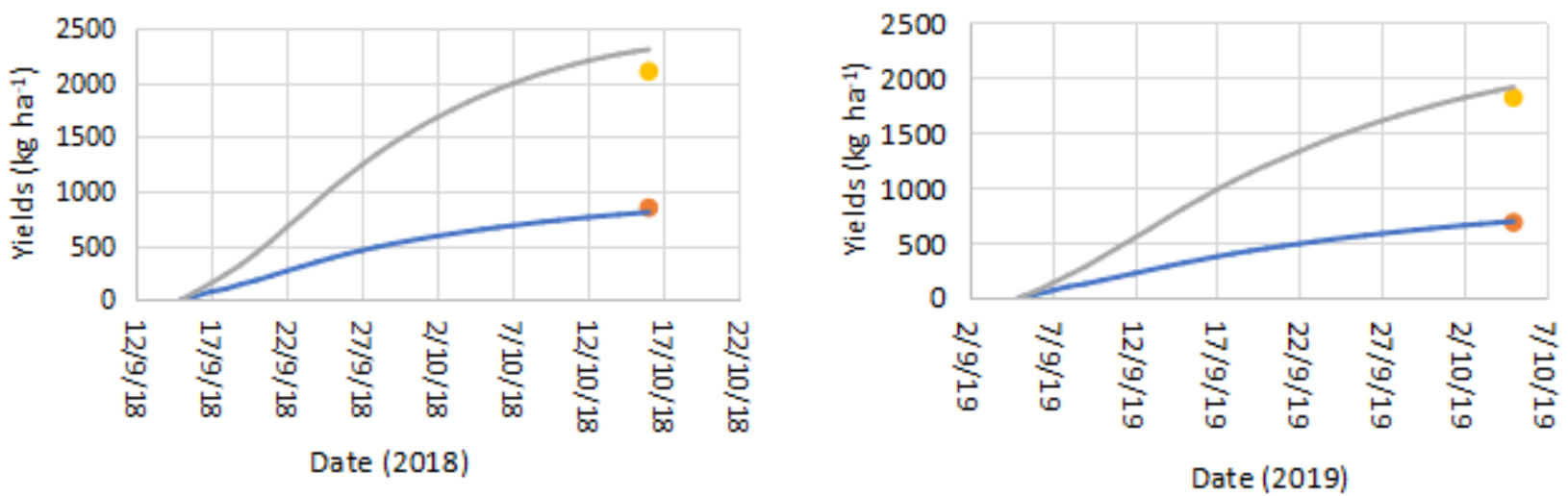


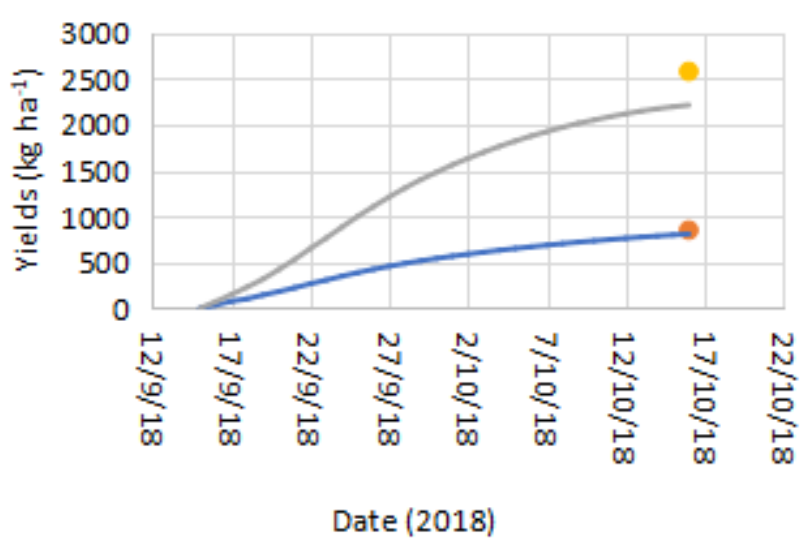

Figure 3. Simulated and observed grain yield responses of three different sources of biochar and inorganic fertilizer on ferric luvisols soil.

Table 4. Effect of biochar and inorganic fertilizer soil amendments on yield and yield characters of upland ricecowpea intercrop.

\begin{tabular}{|c|c|c|c|c|c|c|c|c|c|}
\hline Treatment & $\begin{array}{l}\text { Spad } \\
\text { leave } \\
(\mathrm{m} 2)\end{array}$ & $\begin{array}{l}\text { No. of } \\
\text { tillers }\end{array}$ & $\begin{array}{l}\text { Panicle } \\
\text { length } \\
\text { (cm) }\end{array}$ & $\begin{array}{l}\text { No. } \\
\text { of } \\
\text { panicles } \\
(\mathrm{m} 2)\end{array}$ & $\begin{array}{l}\text { Weight } \\
\text { of } \\
\text { fill } \\
\text { grains } \\
(\mathrm{kg})\end{array}$ & $\begin{array}{l}\text { Weight } \\
\text { of } \\
\text { Unfill } \\
\text { grains } \\
(\mathrm{kg})\end{array}$ & 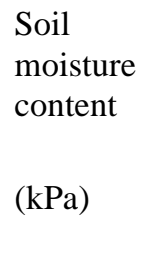 & $\begin{array}{l}\text { No. of } \\
\text { spikelets } \\
\text { per } \\
\text { panicles } \\
(\mathrm{m} 2)\end{array}$ & $\begin{array}{l}\text { Plant } \\
\text { height } \\
\text { At } \\
\text { maturity } \\
\text { (cm) }\end{array}$ \\
\hline $\begin{array}{l}\text { CharCorncob+N45P30K30 } \\
+\mathrm{C}\end{array}$ & 282.24 & 57.50 & 35.15 & 100.5 & 11.57 & 3.29 & 29.66 & 28.500 & 74.24 \\
\hline $\begin{array}{l}\text { CharGroundnutshell+N45P } \\
30 \mathrm{~K} 30+\mathrm{C}\end{array}$ & 276.29 & 46.69 & 38.83 & 98.5 & 12.76 & 2.61 & 27.29 & 31.500 & 69.83 \\
\hline Char Corncob+N45P30K30 & 237.54 & 39.94 & 30.84 & 38.25 & 7.932 & 2.46 & 19.04 & 25.250 & 63.21 \\
\hline $\begin{array}{l}\text { CharGroundnutshells+N45 } \\
\text { P30K30 }\end{array}$ & 226.74 & 42.94 & 30.67 & 33.75 & 9.72 & 2.73 & 19.21 & 21.000 & 65.3 \\
\hline $\begin{array}{l}\text { CharPoultryManure+N45P } \\
30 \mathrm{~K} 30\end{array}$ & 247.91 & 47.94 & 39.61 & 42.75 & 7.99 & 2.59 & 20.08 & 22.750 & 66.45 \\
\hline $\begin{array}{l}\text { CharPoultryManure+N45P } \\
30 \mathrm{~K} 30+\mathrm{C}\end{array}$ & 309.27 & 66.69 & 70.92 & 118.75 & 16.03 & 2.88 & 30.39 & 33.250 & 71.78 \\
\hline Control & 208.71 & 32.69 & 30.61 & 22.5 & 6.102 & 0.89 & 17.11 & 10.000 & 99.61 \\
\hline N90:P60: K60 & 288.38 & 50.13 & 55.90 & 31.25 & 11.23 & 2.84 & 17.46 & 28.250 & 62.69 \\
\hline
\end{tabular}




\begin{tabular}{lccccccccc}
\hline Tukeys HSD & 18.87 & 6.41 & 2.30 & 10.24 & 2.19 & 0.84 & 3.00 & 2.91 & 5.01 \\
$\mathrm{CV}$ & 10.56 & 19.33 & 4.57 & 4.57 & 28.84 & 52.01 & 9.29 & 16.19 & 5.91 \\
\hline
\end{tabular}

Char-biochar, C-cowpea, N-nitrogen, P-phosphorus, K-potassium

Table 5: Effect of biochar and inorganic fertilizer soil amendments on yield and yield characteristics of cowpea intercrop

\begin{tabular}{llll}
\hline Treatment & Plant height $(\mathrm{cm})$ & Pod weight $(\mathrm{kg})$ & Grain weight $(\mathrm{kg})$ \\
\hline Sole cowpea & 79.00 & 18.27 & 135.55 \\
Char corncobs+45N30P30K+C & 160.00 & 5.30 & 3.87 \\
Char groundnutshells+45N30P30K+C & 163.25 & 4.89 & 3.36 \\
Char poultry manure+45N30P30K+C & 167.75 & 6.64 & 4.86 \\
\hline Tukeys HSD & 61.45 & 6.69 & 93.60 \\
CV & 15.94 & 39.58 & 49.03 \\
\hline
\end{tabular}

Char-biochar, C-cowpea, N-nitrogen, P-phosphorus, K-potassium

\section{Discussion}

The simulated and observed biomass responses of upland rice crops on ferric luvisols soil are expressed in (Figure 1). Observed biomass responses on the three different sources of biochar+45N30P30K+cowpea intercrop treatments were significantly $(p<0.05)$ greater than those on the $90 \mathrm{~N} 60 \mathrm{P} 60 \mathrm{~K}$. For the biomass yields for the three different sources of biochar+45N30P30K fertilizer treatments were significantly $(\mathrm{p}<0.05)$ higher than the absolute control. In contrast, only the three different biochar $+45 \mathrm{~N} 30 \mathrm{P} 30 \mathrm{~K}+$ cowpea intercrop treatments provided statistically significant responses on the ferric luvisols. Results for both biochar and inorganic fertilizer show a stronger response to $N$ fertilizer $(N 90)$ than to $P$ fertilizer $(p<0.05)$ and an increased $N$ response $(p<0.05)$ in the presence of $\mathrm{P}(\mathrm{N}$ and $\mathrm{P}$ treatment). The simulated trends in (Figure $2 \mathrm{a}, \mathrm{b})$ are less responsive, with almost no change in predicted yields for absolute control. In fact, simulated biomass yields with addition biochar+45N30P30K+ intercrop is higher than that simulated for the control on each plot, indicating that the model simulated net immobilization and a reduced $\mathrm{N}$ supply for crop growth without the addition of the cowpea intercrop. Simulated responses to application of inorganic $\mathrm{N}$ on both cropping season and $\mathrm{N}+\mathrm{P}$ are close to the observed responses, but there is a large over-prediction for the three different sources of biochar $\mathrm{N}+\mathrm{P}$ treatment. What the model was able to simulate reasonably well were the differences in biomass yields between the three different sources of biochar.

The observed three different sources of biochar, inorganic fertilizer, and cowpea intercrop varied between RMSE $=315.176$ and $460.0358 \mathrm{~kg} \mathrm{ha}^{-1}$ in 2018 and 2019, respectively, for grain yield. In response to a wider range of applied $\mathrm{N}+\mathrm{P}$ for upland rice, the model could reasonably simulate the fluctuation of three different biochar, inorganic fertilizer, and cowpea intercrop sources (Figures 1a, e, $\mathrm{f}$ and Figure 3a, e, f, g). However, as exhibited in Figure 3, the model tends to slightly underestimate three different sources of biochar+45N30P30K. In figure 3 the RMSE of grain yield was 315.18 and $460.04 \mathrm{~kg} \mathrm{ha}^{-1}$ for 2018 and 2019, respectively. The RMSE of biomass was 1981.669 and 3562.842 $\mathrm{kg}$ ha-1 for 2018 and 2019, respectively in figure 1. 
As shown in Figures 1(a, e, f) and 3(a, e, f, g), biomass and grain yield (excluding some data points) fit wider one to one line with optimum $90 \mathrm{~N} 60 \mathrm{P} 60 \mathrm{~K}$ and three different sources of biochar $+45 \mathrm{~N} 30 \mathrm{P} 30 \mathrm{~K}+$ cowpea intercrop data, but the model overestimated when grain yield data were included. On the contrary, the predicted grain yield at the three different sources of biochar was largely overestimated regardless of the three different sources of biochar, inorganic fertilizer, and cowpea intercrop. There was good fitness between simulated and observed three different sources of biochar+45N30P30K when only optimum grain yield data were used (Figure 1b, c, d, and g; Figure $3 \mathrm{~b}, \mathrm{c}, \mathrm{d})$. There was good fitness between simulated and observed three different sources of biochar+45N30P30K when only optimum grain yield data were used (Figure 3b, c, d, and Figure 1b, $\mathrm{c}, \mathrm{d}$, and $\mathrm{g}$ ). However, when $90 \mathrm{~N} 60 \mathrm{P} 60 \mathrm{~K}$ was also included in the validation, model performances were reduced. The RMSE of grain yield was 315.18 and $460.04 \mathrm{~kg} \mathrm{ha}^{-1}$ for 2018 and 2019 , respectively. The RMSE of biomass was 1981.669 and $3562.842 \mathrm{~kg} \mathrm{ha}^{-1}$ for 2018 and 2019, respectively. The result exhibited that the model performance generally decreased when the data of 90N60P60K conditions were included. The goodness of fitness was reduced and RMSE increased for almost all of the growth parameters concerned in Figure 1 and 3. In general, the simulation results overestimated the three different sources of biochar+45N30P30K+ cowpea and 90N60P60K yielded for both treatments, while biochar+45N30P30K was underestimated.

\section{Upland rice-cowpea intercrop}

The observed responses of upland rice to biochar and inorganic fertilizer $\mathrm{P}$ in the farming for the future, UDS-Nyankpala. In the case of rice, biomass yields are significantly higher $(p<0.05)$ for the luvisols in 2019 than for the 2018. There are significant $(\mathrm{p}<0.05)$ increases in biomass response of rice to the three nutrient treatments (biochar poultry manure+45N30P30K+cowpea intercrop, biochar corn cobs+45N30P30K+cowpea intercrop, biochar groundnut shells+45N30P30K+cowpea intercrop) compared with the 90N60P60P and absolute control, and between the nutrient treatments, indicating that upland rice responded to the three different sources of biochar and levels of P input $(60,30 \mathrm{~kg} \mathrm{P} \mathrm{t}$ $\mathrm{ha}^{-1}$ ) and its availability. As APSIM-upland rice is not 'P-aware', simulated biomass can be compared only for the situation where P nutrition can be assumed adequate, in this case the P30 treatment. In Figure 1, simulated biomass of upland rice for the three different sources of biochar compares well with observed yield, but for the biochar poultry manure+45N30P30K+cowpea, biochar corncobs $+45 \mathrm{~N} 30 \mathrm{P} 30 \mathrm{~K}+$ cowpea, biochar groundnut shells $+45 \mathrm{~N} 30 \mathrm{P} 30 \mathrm{~K}+$ cowpea, the simulated yield is actually less than that for the $90 \mathrm{~N} 60 \mathrm{P} 60 \mathrm{~K}$, and substantially less than the observed.

The upland rice model used here (APSIM Version 7) has routines to simulate water stress on plant growth, and over-prediction of this stress seems to be responsible for simulation of the lower yield on the upland rice under absolute control treatment. For the three different sources of biochar $+45 \mathrm{~N} 30 \mathrm{P} 30 \mathrm{~K}+$ cowpea, $85 \%$ of crop days are simulated to have profile water contents indicative of saturation, whereas for the $90 \mathrm{~N} 60 \mathrm{P} 60 \mathrm{~K}$ it is less than $50 \%$ of days. The rice-cowpea intercrop provides an assessment of how well the systems model is able to simulate the combined effects of organic and inorganic N supply. Figure 1 shows the observed and predicted biomass yield of the three different sources of biochar used in upland rice crops in northern Ghana is planted (fertilized with P60 and P30) and receiving two rates of $\mathrm{N}$ fertilizer. From the observed responses to fertilizer N, it is clear that intercropping cowpea in upland rice was able to supply all of the upland rice crop $\mathrm{N}$ requirements on ferric luvisols soil. The model was able to predict very closely the observed biomass responses for 
the respective different biochar along with the response to $\mathrm{N}$ fertilizer inputs on each plot (Figure 1). It should be noted that, for both the simulated and observed three different sources of biochar and inorganic fertilizer on upland rice, all above-ground biomass from the preceding upland rice was removed, and the carryover of $\mathrm{N}$ from the rice grain is via the rice straw material. Hence, results in (Figure 1) suggest that the model is able to simulate these biochar organic $\mathrm{N}$ benefits, and interaction with inorganic $\mathrm{N}$, with a high degree of precision.

In these experiments, measured yield responses for cowpea and upland rice were attributed to three different sources of biochar, $\mathrm{P}$ and $\mathrm{N}$ responsive soils. However, the results of simulation of the observed $\mathrm{P}$ responses and interaction with $\mathrm{N}$ supply in the upland rice plant were not disappointing, showing sensitivity to inputs of three different sources of biochar and inorganic $\mathrm{P}$ and $\mathrm{N}$ levels (i.e., biochar+45N30P30K+cowpea and P60 treatments). Application of APSIM to simulate the northern Ghana data is one of the early experiments at the exploitation of the unique $\mathrm{P}$ abilities on an independent data set. Results attained here certainly replicate a measure of naivety with parameterizing this novel model. Probert (2004) has recommended that the impediment in parameterizing the model is mainly related to explicitly the $\mathrm{P}$ position in terms of $\mathrm{P}$ sorption and labile $\mathrm{P}$ in each plot of soil. Additional investigative amendments to input parameters, particularly the percentage factor between measured Olsen $\mathrm{P}$ and labile $\mathrm{P}$, are undoubtedly appropriate (Micheni et al., 2004) and how this might differ between soils, and maybe with soil depth. The alternative parameter that may permit consideration in the P uptake aspect that Probert (2004) proposes is crop type and variety. In this study, the P supply aspect was set to 2 .

However, the most concern with the model is that the insensitivity of upland rice plant response to biochar and $\mathrm{P}$ involvement at the low-slung $\mathrm{N}$ levels. Part of this challenge may cause the calibration process used for labile P. For the upland rice crop responses used in this experiment, moisture stress, at least owed to deficits, can be reduced. Henceforth, the results recommend further stimulating of the model is obligatory for situations where both $\mathrm{N}$ and $\mathrm{P}$ are limiting plant growth. The model data set would have crop growth response to each component computed in the appearance of appropriate levels of the biochar, in addition to limiting levels of both $\mathrm{N}$ and $\mathrm{P}$. This would help overcome some of the calibration difficulties met in this present study.

The APSIM-upland rice model (Robertson et al., 2001) has also not been extensively evaluated against field-observed growth responses. While the $\mathrm{P}$ effects on upland rice crop growth within the trials cannot be considered at this point, simulation of the P30 treatment for the sandy soils provided some beneficial sensitivities. Biochar in terms of water deficits practices in upland rice and the soil water retention parameters for the ferric luvisols permits faster attention. The close potential between observed and predicted biomass at absolute control for the cowpea intercrop crop (Figure 1) recommends that the model captures very well the main mechanisms beneficial to enhanced soil $\mathrm{N}$ supply in upland rice. In the earlier, APSIM has revealed to achieve well in simulating inorganic $\mathrm{N}$ supply ensuing biochar+ 45N30P30K inputs (Berghuijs et al., 2021) and crop response to 90N60P60K and biochar+ 45N30P30K+cowpea intercrop (Tsubo et al., 2005; Shamudzarira et al., 2000). Simulation of the upland rice-cowpea intercrop in this experiment has protracted assessment to the northern Ghana, upland rice variety and three different sources of biochar are important to sandy soil in Guinea savanna agricultural systems. The experiment has also emphasized the need to cover the $\mathrm{P}$ stress practices to other upland rice and cowpea crops commonly grown by smallholder farmers in northern Ghana. 


\section{Effects of biochar on upland rice-cowpea intercropping systems on yield and yield components of upland rice}

Tables 4 shows the impact of three different sources of biochar and inorganic fertilizer on the yield and yield components of upland rice-cowpea intercrop. In the intercrop cropping, the number of tillers per square meter of land of biochar+45N30P $30 \mathrm{~K}+$ cowpea on upland rice was significantly $(\mathrm{P}<0.05)$ higher than in the $90 \mathrm{~N} 60 \mathrm{P} 60 \mathrm{~K}$ treatment. The number of panicles per square meter was significantly $(\mathrm{P}<0.05)$ larger in the biochar+45N30P30K+cowpea treatment than in the 90N60P60K treatment when compared to the alternate hills and rows. In terms of the number of panicles, there were significant variations $(\mathrm{P}<0.05)$ in the cropping systems between the 90N60P60K and biochar+45N30P30K. The biochar+45N30P30K+cowpea cropping system had the longest panicle length per hectare, while the biochar+45N30P30K cropping system had the shortest. In terms of soil moisture content for grain development, however, there were significant variations $(\mathrm{P}<0.05)$ between the three different sources of biochar+45N30P30K+cowpea cropping systems in terms of number of spikelets, grain yield, 1000-grain weight, filled grain and unfilled grain than 90N60P60K. Plant height was higher in biochar+45N30P30K+cowpea on upland rice than in the $90 \mathrm{~N} 60 \mathrm{P} 60 \mathrm{~K}$ cropping system, alternate rows, and then alternate hill cropping systems (Table 4).

\section{Effects of rice-cowpea intercropping systems on yield and yield components of cowpea.}

Table 5 shows the effects of three distinct sources of biochar and inorganic fertilizer on the yield and yield components of cowpea (CP) in rice-cowpea intercropping systems. Cowpea plant height and grain yield were not significantly different for any of the three different sources biochar+ $\mathrm{C}$ cropping systems. Cowpea plant height was not considerably higher under sole cowpea intercropping than under alternate hills and rows cropping (Table 5). Cowpea plant height was also much higher when intercropped with rice than in other cropping systems. Cowpea pod weight was highest when grown as a single crop and lowest when grown in intercropping systems with upland rice. Cowpea pod weight had almost the similar values for all the intercropping systems with upland rice.

\section{Conclusion}

The farming for the future experiment was carried out in a very diverse environment and on a very varied soil to those on which the ideas in the APSIM phosphorus procedures were initially developed and verified. Especially, this is a location with intermittent rainfall where the model predicted that moisture stress did not disturb plant growth, and the soil, a ferric Luvisols, has increase P-sorption characteristics. The data set used to simulate the behaviour of $\mathrm{P}$ in the soil and the $\mathrm{P}$ concentrations and uptake by upland rice was based on plant grown on a low P-sorbing soil in a Guinea savannah environment. The model executed well in predicting the growth of upland rice crops from different rates of $\mathrm{P}$ treatments. Another factor was that the $\mathrm{N}$ and biochar inputs led to different plant growth in the two cropping seasons. The predicted moisture content, $\mathrm{P}$ and $\mathrm{N}$ stresses were beneficial in supporting to know the motives for the variations in retort to $\mathrm{N}$ and $\mathrm{P}$ inputs in the two cropping seasons. This is the initial situation where $\mathrm{P}$ form of the upland rice model was verified under conditions where $\mathrm{N}$ stress was also an issue. The result from the model proposes that simulation of plant growth with two potential restrictive nutrients was feasible. Olsen P data was used for priming the labile $\mathrm{P}$ of the model. The soil $\mathrm{P}$ data was attained for samples taken after harvest. There was slightly meager pact between the predicted differences in labile $\mathrm{P}$ and the soil $\mathrm{P}$ data. 
The results showed a positive interaction effect of the incorporation of three different sources of biochar on the upland rice-cowpea intercrop with inorganic fertilizer. In terms of rice yields, the study found that biochar interaction with $\mathrm{N}$ and $\mathrm{P}$ was generally comparable to the interaction with ricecowpea intercrop. While the results showed that sole treatment increased rice yields, applications did not. There is no doubt that inorganic fertilizer and intercropping in agroecosystems are beneficial. However, it shows that in areas with insufficient $\mathrm{N}$ and $\mathrm{P}$, cowpea intercrop could be used in combination with three different sources of biochar to improve soil productive capacity and crop yields in smallholder agroecosystems. In the presence of a companion crop, cowpea, there were significant differences in yields and yield components of the three different sources of biochar on upland rice-cowpea intercrop and $\mathrm{N}$ and $\mathrm{P}$. Although not significantly different from the other intercrops, alternate rows of upland rice and cowpea consistently yielded greater numerical cowpea grain yields. Yields of upland rice-cowpea intercrop under biochar plus inorganic fertilizer plus Cowpea intercrop were generally higher than inorganic fertilizer. In conclusion, the improved performance of three different sources of biochar+45N30P30K+cowpea intercrop under diverse $\mathrm{N}$ and $\mathrm{P}$ regimes demonstrated its advantage, thus recommending it to small-holder farmers with an $\mathrm{N}$ application of $30 \mathrm{~kg} \mathrm{ha}^{-1}$. Top-dressing of $\mathrm{N}$ fertilizers at 8 weeks could be more advantageous than a full dose of $\mathrm{N}$ at the time of transplanting, imparting a higher yield. The analysis of the APSIM model results showed the strong dependency of the biochar+45N30P30K+cowpea intercrop upon plant $\mathrm{N}$ and $\mathrm{P}$ uptake and growth under ferric Luvisol soil. The modeling results for $\mathrm{N}$ and $\mathrm{P}$ under ferric Luvisol soil showed that they could be utilized as a decision support tool under different biochar+45N30P30K+cowpea intercrop to have good management options.

\section{Acknowledgments}

The field experiment was self-finance. Education and Supervisor support from the Department of Agricultural Engineering, University for Development Studies under the Faculty of Agriculture-Soil and Water Conservation and Management Department (2019-2021). The Soil Research Institute is thanked for laboratory analyses. I thank Dr. Kofi Frimpong-Anin, Umar Sanda, Gabriel Willie Quansah and Dr. Joseph Kudadam Korese for helpful comments in this manuscript.

\section{References}

Agegnehu, G., Srivastava, A. K., and Bird, M. I. (2017). The role of biochar and biochar-compost in improving soil quality and crop performance: A review. Applied soil ecology, 119, 156-170.

Atakora, W. K., Fosu, M., Abebrese, S. O., Asante, M., and Wissuwa, M. (2015). Evaluation of low phosphorus tolerance of rice varieties in northern Ghana. Sustainable Agriculture Research, 4(5262016-37967).

Ayaga, G., Todd, A., and Brookes, P. C. (2006). Enhanced biological cycling of phosphorus increases its availability to crops in low-input sub-Saharan farming systems. Soil Biology and Biochemistry, 38(1), 81-90.

Baatuuwie, B. N., Nasare, L. I., and Tefuttor, E. G. (2020). Biochar as an alternative growth medium for tree seedlings in the Guinea Savanna Zone of Ghana. African Journal of Plant Science, 14(7), 248253.

Berghuijs, H. N., Weih, M., van der Werf, W., Karley, A. J., Adam, E., Villegas-Fernández, Á. M., and Vico, G. (2021). Calibrating and testing APSIM for wheat-faba bean pure cultures and intercrops across Europe. Field Crops Research, 264, 108088. 
Blake, G. R. (1965). Bulk density. Methods of Soil Analysis: Part 1 Physical and Mineralogical Properties, Including Statistics of Measurement and Sampling, 9, 374-390.

Blake, G. R., and Hartge, K. H. (1986). Particle density. Methods of soil analysis: Part 1 physical and mineralogical methods, 5, 377-382.

Bray, R. H., and Kurtz, L. T. (1945). Determination of total, organic, and available forms of phosphorus in soils. Soil science, 59(1), 39-46.

Bremner, J. M. (1965). Total nitrogen. Methods of Soil Analysis: Part 2 Chemical and Microbiological Properties, 9, 1149-1178.

Dimes, J. P., and Revanuru, S. (2004). Evaluation of APSIM to simulate plant growth response to applications of organic and inorganic $N$ and $P$ on an Alfisol and Vertisol in India. In Aciar Proceedings (pp. 118-125). ACIAR; 1998.

Ekekpi, G. K., and Kombiok, J. M. (2008). Report on baseline study in three target districts of conservation agriculture project in Northern Ghana. Care International Report.

FAO-UNESCO, 1988; Soil map of the world (Revised legend)

Glaser, B., Lehmann, J., and Zech, W. (2002). Ameliorating physical and chemical properties of highly weathered soils in the tropics with charcoal-a review. Biology and fertility of soils, 35(4), 219230 .

Imoro, Abukari Ziblim, Daniel Okai-Anti, and E. Augustine Asmah. "Productivity index rating of some soils in the Tolon/Kumbungu district of the Northern region of Ghana." (2012).

Klute, A., and Page, A. L. (1986). Methods of soil analysis. Part 1. Physical and mineralogical methods; Part 2. Chemical and microbiological properties (No. BOOK). American Society of Agronomy, Inc.

Kombiok, J. M., Buah, S. S. J., and Sogbedji, J. M. (2012). Enhancing soil fertility for cereal crop production through biological practices and the integration of organic and in-organic fertilizers in northern savanna zone of Ghana. Soil Fertility, 1.

Kombiok, J. M., Safo, E. Y., and Quansah, C. (2005). Yield and nitrogen fixation of cowpea as affected by tillage and cropping systems in the Northern Savanna Zone of Ghana. West African Journal of Applied Ecology, 7(1).

Konlan, S. (2010). Groundnut varietal response to spacing in the Guinea Savannah and Forest Zones of Ghana (Doctoral dissertation).

Kookana, R. S., Sarmah, A. K., Van Zwieten, L., Krull, E., and Singh, B. (2011). Biochar application to soil: agronomic and environmental benefits and unintended consequences. Advances in agronomy, 112, 103-143.

Lal, R. (2015). Restoring soil quality to mitigate soil degradation. Sustainability, 7(5), 5875-5895.

Lal, R. (2020). Soil organic matter content and crop yield. Journal of Soil and Water Conservation, 75(2), 27A-32A.

Laird, D. A., Brown, R. C., Amonette, J. E., and Lehmann, J. (2009). Review of the pyrolysis platform for coproducing bio-oil and biochar. Biofuels, bioproducts and biorefining, 3(5), 547-562.

Lehmann, J., Gaunt, J., and Rondon, M. (2006). Bio-char sequestration in terrestrial ecosystems-a review. Mitigation and adaptation strategies for global change, 11(2), 403-427.

Micheni, A., Kihanda, F., and Irungu, J. (2004). Soil organic matter (SOM): The basis for improved crop production in arid and semi-arid climates of eastern Kenya. Managing nutrient cycles to sustain soil fertility in sub-Saharan Africa, 608.

Musah, M. A., Baba, I. I., Dogbe, W., Abudulai, M., Mutari, A., and Haruna, M. (2013). NERICA intercrop systems and their influence on yield components and productivity of NERICA and partner crops in the Guinea Savannah Zone of Ghana. International Journal of AgriScience, 3(12), 881-893. 
Nelson, D. W., and Sommers, L. E. (1996). Total carbon, organic carbon, and organic matter. Methods of soil analysis: Part 3 Chemical methods, 5, 961-1010.

Owusu-Bennoah, E., Ampofo, J. G., and Acquay, D. K. (1995). Phosphorus status of some semi-arid agricultural soils of northern Ghana. Ghana journal of agricultural science, 28, 29-36.

Probert, M. E. (2004). A capability in APSIM to model phosphorus responses in crops. In ACIAR PROCEEDINGS (pp. 92-100). ACIAR; 1998.

Puziy, A. M., Poddubnaya, O. I., Martínez-Alonso, A., Suárez-García, F., and Tascón, J. M. D. (2002). Characterization of synthetic carbons activated with phosphoric acid. Applied surface science, 200(1-4), 196-202.

Robertson, M. J., Carberry, P. S., Chauhan, Y. S., Ranganathan, R., and O'leary, G. J. (2001). Predicting growth and development of pigeonpea: a simulation model. Field Crops Research, 71(3), 195-210.

Sanchez, P. A., Palm, C. A., and Buol, S. W. (2003). Fertility capability soil classification: a tool to help assess soil quality in the tropics. Geoderma, 114(3-4), 157-185.

Shamudzarira, Z., and Robertson, M. J. (2002). Simulating response of maize to nitrogen fertilizer in semi-arid Zimbabwe. Experimental Agriculture, 38(1), 79-96.

Simpson, R. J., Oberson, A., Culvenor, R. A., Ryan, M. H., Veneklaas, E. J., Lambers, H., and Smith, S. E. (2011). Strategies and agronomic interventions to improve the phosphorus-use efficiency of farming systems. Plant and Soil, 349(1-2), 89-120.

Tsubo, M., Walker, S., and Ogindo, H. O. (2005). A simulation model of cereal-legume intercropping systems for semi-arid regions: I. Model development. Field crops research, 93(1), 10-22.

Verheijen, F., Jeffery, S., Bastos, A. C., Van der Velde, M., and Diafas, I. (2010). Biochar application to soils. A critical scientific review of effects on soil properties, processes, and functions. EUR, 24099, 162. 